\title{
The Development of Civic Engagement to Empower Student Potential Through Entrepreneurial Student Program (PMW)
}

\author{
C. Darmawan, Syaifullah, L. Anggraeni \\ Universitas Pendidikan Indonesia \\ cecepdarmawan@yahoo.com
}

\begin{abstract}
- the young generation is a figure of potential existence into hope to realize the ideals of community, state and nation. With qualified young generation, it is possible to realize these ideals. Conversely, the lower the quality of the younger generation, then it would only be a burden in the implementation of development of a nation. The potential of the younger generation, an absolute must properly empowered through various positive measures so diverse potential inherent in the younger generation can be actualized properly. Community Civic emphasis on participation and act as citizens in the social life in the neighborhood. Civic Engagement is one of the main concepts in Community Civic emphasis on citizen involvement in various aspects of life. Student Entrepreneurial Program is one program offered by the Higher Education in order to develop students' potential as a prospective entrepreneur is very important for the progress and independence of the nation. Student entrepreneurship program encourages students to develop independent attitudes and behavior, cooperation, business opportunities to become entrepreneurs as a preparation for life in society
\end{abstract}

Keywords - civic community, civic engagement, civics, empowerment, entreprenuership.

\section{INTRODUCTION}

At this time. The number of unemployed young people, College graduates are no exception is still very high. This can be seen on the basis of data of the Central Bureau of statistics that in 2011, recorded 455,367 graduate Diplomas I, II, III, and the Academy. While University graduates as much 619,617 as unemployment. This means that college graduates still reach $13.07 \%$ of total unemployment in the year i.e. $8,220,081$ people. This condition is aggravated with the rate of growth of the labor force that is always greater than field work each year. These conditions, it will certainly give rise to a growing number of greater unemployment figures from year to year.

According to BPS data, until in February 2014, a graduate program diploma/academy as much as 195,258. While unemployment stemming from university graduates as many as 398,298 people. If the combined amounted to
$8.30 \%$ of a total of $7,147,069$ people unemployed in Indonesia. Figure 1 shows derivation unemployment diploma/academy and university graduates.

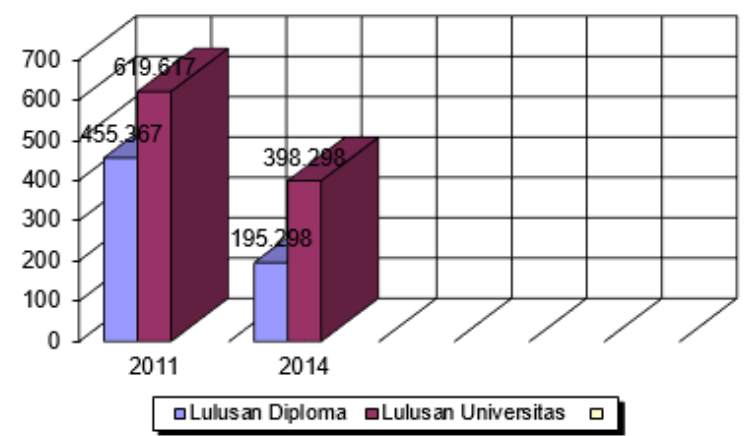

Fig. 1. Unemployment diploma/academy and university graduates the year 2011 and 2014 (in thousands)

Based on the above chart shows unemployment figures decline that comes from the diploma/academy program and university graduates, one of which as a positive implications of various entrepreneurial activities undertaken by students, through programs of entrepreneurial activities. Entrepreneurship program are facilitated by an umbrella activity PMW (Student Entrepreneurial Program) from Kemdikbud, as well as higher education Ditjen initiated by student organizations at the level of courses, faculty or University. These programs are very important as a strategic attempt to give birth to a new entrepreneurs.

To lower unemployment, its breakthrough programs needed to give birth to new entrepreneurs-entrepreneurs among students. This research try researching about potential student empowerment through entrepreneurship program towards self-reliance of communities and Nations. Researchers believe that this issue needs to be examined in an effort to formulate ideas about the implementation of civic engagement that was instrumental in empowering students through Student Entrepreneurship Program or Student Entrepreneurial Program (PMW). 


\section{LITERATURE REVIEW}

\section{A. Community civic and civic engagement}

As propounded Somantri (2001, PG. 282) that the movement of community civics pioneered by W.A. Dunn in 1907 at the commencement of the functionalization want more civics lesson for the students with their environment or to confront daily life in relation to the scope of local, national and international level. In the context of Civics community, one of the important concepts studied deals with civic engagement or involvement of citizens. American Psychologist Association (2012) defines civic engagement as an "Individual and collective actions designed to identify and address issues of public concern." Based on this definition, the involvement of citizens is the Act of an individual and joint actions which are designed to identify and attention to public issues.

Meanwhile, Korten (1998) defines civic engagement "... is about the right of the people to define the public good. Determine the policies by which they will seek the good, and the reform or replace institutions that do not serve that good. Namely with regard to the rights of people to interpret the common good, determine policies through they will seek goodness, and to change or put back the institutions that do not the good of it.

\section{B. Empowerment of student/young generation as a member of the philosophical society as the basis of the involvement of citizen}

According to Stewart (1994) empowerment or empowerment is defined as a quality internal power personality of individuals or organizations in realizing and adjust to the environment. As for the orientation of empowerment include Excellence (excellence), progress (progress), sustainability (existence). Youth empowerment boils down to an increase in the role of young people in various fields and aspects of life of society, nation, and State.

As for the pattern of the construction of the younger generation must include the following elements:

- Pattern of its holistic nature, i.e., whole or comprehensive covering various dimensions of coaching the young generation, which includes the potentialities of youth.

- Focus the goal is personal empowerment as a source of human strength.

- Its construction is the Central harmonious families in over the cornerstone values religious.

- Root/basis its construction include: rooted in religious values; rooted in local cultural harmony and national culture.

- The nuances of coaching namely by implementing the paradigm of education (Educational Paradigm) in the form of psychological approaches.

\section{Review about the community and the development community}

A Community (community) are the groups or entities on the basis of the area that did not have the interests of the specifically (Soekanto, 1998). In the meantime, to understand the meaning of the development community, need to take a view Kubish (2002. PG. 2) as follows:

Community Building, as the definitions below indicate, emerged as a way to engage residents of poor communities in solving their own problems. It describes an approach which emphasizes:

1. Communities working together to identify and solve their problems

2. Cultivation of socially valuable relationships

3. Support for leadership development and increased human capital

4. Increased relational and organizational skills of residents and groups

5. Hurricane stakeholder engagement

6. The Development of a sense of common purpose and an action agenda

7. Increased local institutional capacity

Seven indicators as presented above is the hallmark of the development community should appear in a community. In the framework of community development, then it is very important the need for good and Community competence or the ability of the community members.

\section{Understanding the young generation}

As it was agreed that both young men are those aged 15-35 years. Because this is the age of appearing in various attitudes, and behaviors of emphasize that idealism, revolutionary, reactionary, and thrilling (Guiseppe Ferrari, 1972). Meanwhile, John Stuart Mill, argued, that the period of youth or youth marked by mental attitude and maturity, ability participate in the context of people's lives.

Meanwhile, Chris Agryris (1961) holds that personal profile mental attitude is characterized by ripe stuff i.e. (1) active; (2) independent (free from the pressure of the outside person); (3) have a very powerful special interests; (4) have the idealism; (5) have strong awareness; and (6) strong self-control.

\section{E. The meaning of Entrepreneurship (entrepreneurship, goals, targets and benefits of PMW)}

The meaning of the Entrepreneur is (1) a person who bore the risk; (2) a person who takes care of the company; (3) people who mobilize and allocate capital; (4) the person who created the new stuff, and so on. Meanwhile, in the library business, some American scholars give the meaning as an individual activity or entrepreneur group opened a new venture with the intent to gain an advantage, keeping the effort and raised him, in the field of the production or distribution of goods or economic services (Manic, 2014.26 pp.). 
Student Entrepreneurial program is instrumental to developing the capacity of institutions in colleges who manage and develop entrepreneurial education program on an ongoing basis. The program is distributed by college graduates who are likely to be job seekers, college graduates are less able to be creative within the difficulties and limitations, and weak relevance of learning environments in higher education or the workforce.

Some goals out of activities, namely PMW

1. Changing the mindsets of college students from a jobseekers (job seeker) being a creator of work (job creator).

2. Fostering entrepreneurship motivation among students.

3. Build a mental attitude of self-employment namely confident, aware of his true identity, motivated people to achieve a goal, never give up, be able to work hard, creative, innovative, daring to take risks with calculation, and leaders have behaved vision forward, responsive to suggestions and criticism, has the ability of empathy and social skills.

\section{METHODS}

This research used a qualitative and quantitative approach to the design of Research and Development ( $R$ D \&) version of the Borg and Gall (1983). Design by R D $\&$ is expected to generate new product development model of Civic Engagement to empower student potential through Entrepreneurial Student Program (PMW).

The location of the research is on the campus of the UPI, with a research subject is a student who is following the activities of UPI PMW in 2014 and 2015. Another subject was the organizer of PMW UPI in this case is the Directorate of Student Affairs Coaching UPI. As for the design of the research can be seen in figure 1 .

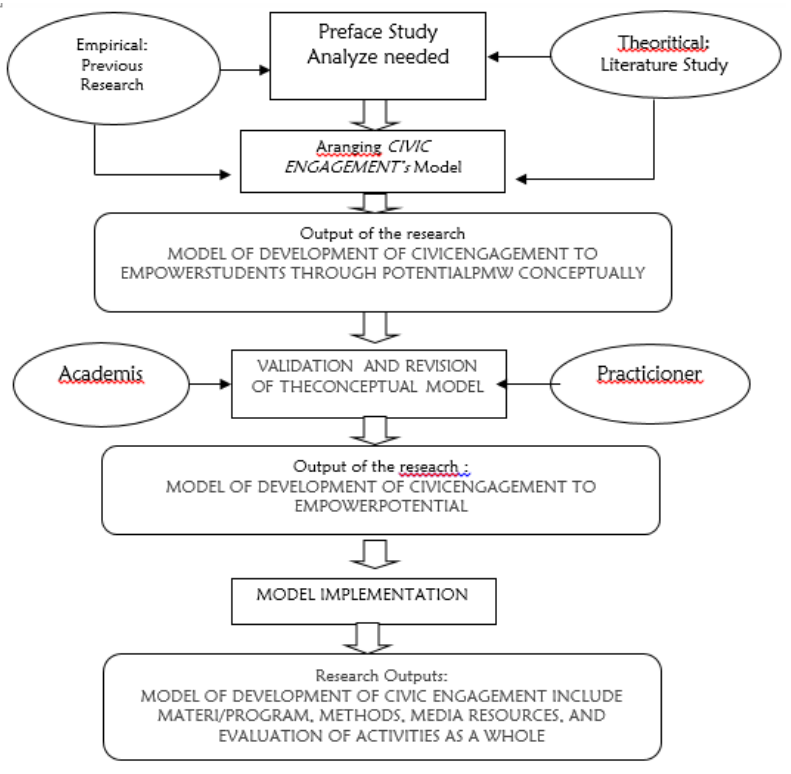

Fig. 2. The procedure of research

\section{RESULTS AND DISCUSSION}

Information obtained related student programs PMW through various media, i.e. almost half of it (41.67\%) obtained information from friends. While the next source of information through social media such as facebook, tweeter, WA of, $\%$. The percentage figure is equal to a percentage of the UPI page (www.upi.edu). Meanwhile, only a fraction are gained through the page or site and pages of higher education faculty, each of $11 \%$ and $2.78 \%$.

Then more than half of it $(55.56 \%)$ the preparation of proposals of activities carried out by all members of the WMP is involved. Only a small portion is done by some members $(19 \%)$, by one of the members $(11 \%)$, and by all members of the supervising lecturer referrals $(5.56 \%)$. This data shows that the initiative and student to work on a proposal of community activities PMW is quite good, which is characterized by good cooperation in the process of drafting proposals PMW. The involvement of lecturers supervisor appears to be not yet optimal, where only the $5.56 \%$ who said that in the process of drafting a proposal involving the direction of a supervising lecturer PMW.

With regard to the composition of the group activities PMW, almost entirely $(83.44 \%)$ consist of one student jurusan/prodi. Only a small part of the course each of $5.56 \%$ and $2.78 \%$ consists of two students department in the faculties of the berda Friday, and consists of students of various departments in the faculty. According to the respondents, this PMW activities dimonitoring and evaluated by both parties as a higher education funders $(61.11 \%)$ as well as by UPI Dirmawa (\%). Meanwhile, only a small percentage $(11 \%)$ who say never done the PMW activity monitoring implementation.

Furthermore, related how to understand and dig into the potential of the community through the activities of the PMW. more than half of the respondents $(52.78 \%)$ agree with the view that through related activities PMW, participants learn to understand and dig into the potential of the community. Meanwhile, nearly half of the respondents $(41.67 \%$ ) said very much agree, and just as a small $(56 \%)$ of the respondents who expressed doubts against it.

Based on the results of the interviews also showed that through the PMW, students were moved to see business opportunities that can be created (job creator) rather than waiting or looking for employment (job seeker) in the community which is indeed limited. Student participants PMW acknowledged that turns business opportunities always exist if there is the will and ability of the student to use it properly.

Although it is recognized that the capital is still considered less, but very helpful to open business opportunities especially as a challenge for the preparatory college later. In addition, other valuable experiences are (1) learning to design the type of business, make decisions quickly and wisely when faced to various problems emerging in the running PMW, (2) to manage the business in an honest and responsible, (3) in collaboration (teamwork) are steady and trust each other, (4) learn to resolve problems that arise, (5) not fast despair or give up. This is in accordance with the compliance with the characteristics that must be owned by the younger generation (Simandjuntak, 1985). 
One of the participants of the PMW named Ade Roni holds that WMP is indeed very demanding activities cooperation, independence, creativity, hard work, discipline, tenacious, believe in the ability in carrying out the activities of the PMW. If analyzed, both participants of the student opinion PMW or WMP Manager in UPI have intersection in terms of benefits that accrue to the students student potential through the development of IE activities PMW, as valuable stock to compete in the society while graduated from the bench and associated costs. Theoretically, the experience of the students followed the PMW activities very relevant to student involvement as citizens (civic engagement) which substantively pertains to the ability of cooperation (working together) in the life of the community to achieve the common goal that is expected (Jacoby, 2009). Based on the results of processing the now presented and filled out by the participants, obtained the data as PMW in figure 3 .

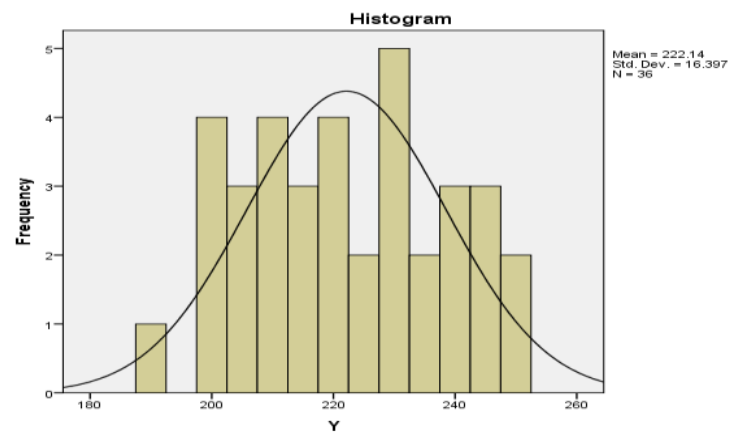

Fig. 3. Processing data of participant

Refer to the above histogram, retrieved value mean to know the response of students to the development of civic engagement to empower the potential of students through the student program is a self-employment 222.14. By doing the classification category against 5 option answers of 54 item statement, then retrieved the classification in figure 4.

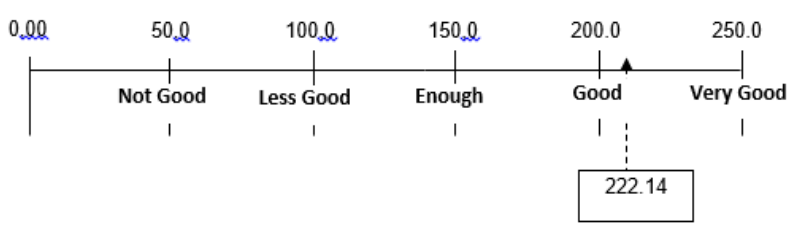

Fig. 4. classification of respondents' answers

The classification is based on the less well it can be said that, in response to the development of students ' civic engagement to empower student potential through entrepreneurial student program belongs in the category of ' good'.

Activities implemented by the PMW student participants PMW, not closing the possibility is exposed to some constraints. Based on the results of the interviews to participants of such constraints, PMW, among others, is still a lack of coordination among fellow members of the Group's own meager PMW three people. Although most of the PMW group coming from a program of study, but the inevitable reality is weak coordination among them. It is recognized by the student badly there is the effectiveness of the activities of the PMW less maximum. The cause of the lack of coordination among the members of one is the intensity of communication is lacking, as effected by the busyness or each Member's activities, whether in the academic activities in the campus as well as off-campus activities.

Based on the results of the research shows that efforts made by students or University parties in overcoming obstacles faced in developing students ' potential for empowerment as PMW UPI as follows:

- Intensifying communication among fellow members of the WMP, with scheduling a meeting to discuss matters related to the activities of the PMW.

- To intensify guidance conducted by professors supervising to PMW, to discuss progress (progress) activities PMW has accomplished.

- carry out follow-up (follow-up) post activities monitoring and evaluation has been done by Dirmawa.

\section{CONCLUSION}

Based on the findings and discussion of the results of the research, then the General conclusions of this research is that the entrepreneurial Student Program (PMW) contributes critical in developing the involvement of citizen (Civic Engagement) mainly as a vehicle for students to develop the potential of the younger generation. Important contributions include via PMW students trained and coached to be sensitive to the problem especially regarding opportunities to work, and able to make decisions intelligently and courageously in opening business opportunities in accordance with his/her abilities, courageous in anticipation and took away the possibility of the risk of failure of the businesses that responded positively.

\section{REFERENCES}

[1] Jacoby, B. 2009. Civic Engagement in Higer Education: Concepts and Practices. United States: Jossey-Bass A Wiley Imprint.

[2] Bringle. R.B \& Muthiah. R.N. 2010. The Role of Service Learning on the Retention of First-Year Students to Second Year. Michigan Journal of Community Service. Spring 2010. 38-49.

[3] Milner. H. 2002. Civic Literacy. How Informed Citizens Make Democracy Work. Hanover. University Press of New England.

[4] Saltmarsh, J \& Zlotkowski. E. 2011. Higher Education and Democracy. Essay on Service Learning and Civic Engagement. Philadelphia: Temple University Press

[5] Somantri, M.N. 2001. Menggagas Pembaharuan Pendidikan IPS. Bandung : Rosda Karya dan PPS UPI

[6] Sukanto, S. 1998. Sosiologi Suatu pengantar. Jakarta : Radjawali Press.

[7] Sumaatmadja, N. 1998. Manusia dalam Konteks Sosial, Budaya, dan Lingkungan Hidup. Bandung : Alfabeta

[8] Supriatna, T. 1997. Birokrasi Pemberdayaan dan Pengentasan Kemiskinan. Bandung: Humaniora Utama Press (HUP)

[9] Wahab, A. A. Dan Sapriya. 2011 Teori dan Landasan Pendidikan Kewarganegaraan. Bandung : CV. Alfa Beta

[10] Winarto, P. 2005. The Leadership Wisdom. Jakarta: Elex Media Komputindo. 